\title{
A Comparative Study on Self-Perceived Health of Cyclists and Inactive Persons in Croatia
}

1 Vanja Lovretić

2 Tomislav Benjak

3 Gorka Vuletić

2 Željka Draušnik

1 Psychiatric Hospital "Sveti Ivan”, Jankomir 11, Zagreb, Croatia

2 Croatian Institute of Public Health, Zagreb, Croatia

3 University J. J. Strossmayer in Osijek, Faculty of Humanities and Social Sciences, Department of Psychology, Osijek, Croatia

\section{Abstract}

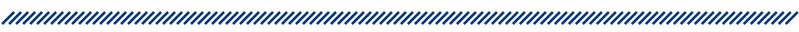

Aim: The aim of this study was to compare the self-perceived health of persons who regularly (three or more times a week) use a bicycle as a means of transport with that of completely or mostly (less than three times a week) inactive persons in Croatia.

Methods: The study included 108 persons who used a bicycle three or more times a week, for longer than half an hour. The average respondent age was 37 . Sixty-six respondents were men (61\%), 42 women (39\%). The control group comprised 100 persons with the average age of 39. Among control respondents, 58 were men $(58 \%)$ and 42 women (42\%). Health was self-assessed by means of a health status questionnaire - the Croatian version of SF-36.

Results: A statistically significant difference was observed in all health dimensions between cyclists and inactive persons. The poorest health dimensions in physically inactive individuals were vitality and energy, psychological health, and role limitation due to emotional problems. A total of $42.6 \%$ cyclists and no more than $17 \%$ of their inactive counterparts declared having better health than last year. A difference was also observed in the segment of health deterioration relative to a year ago $-30 \%$ of inactive participants stated their health worsened compared to a year ago, as did $8 \%$ of cyclists. While $4 \%$ of inactive respondents felt their health deteriorated drastically, no cyclists thought likewise.

Conclusion: Cyclists perceived their health significantly better than the physically inactive respondents. Lifestyle factors that affect health self-assessment could be an important explanation.

Keywords: cyclists, health self-assessment, physical activity, physical inactivity, Croatia

Article received: 10.11.2015.

Article accepted: 15.10.2017.

DOI: $10.24141 / 1 / 3 / 2 / 3$

Author for correspondence:

Vanja Lovretić

Jankomir 11, 10090 Zagreb, Croatia

Tel: +38513430000

E-mail: vanja.lovretic@yahoo.com 


\section{Introduction}

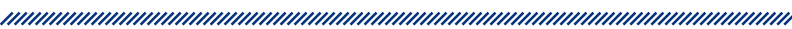

The World Health Organization (WHO) defines physical activity as "any bodily movement produced by skeletal muscles that requires energy expenditure"1. The level of physical inactivity has increased in many countries and is presently associated with 3.2 million deaths per year, 670000 premature deaths in people under 60 , and around $30 \%$ of diabetes and ischemic heart disease burden. Physical inactivity has been identified as the fourth leading risk factor for global mortality $(6 \%$ of deaths globally) ${ }^{2}$. WHO recommends to all healthy adults aged 18-64 to do at least 150 minutes of moderate-intensity physical activity throughout the week. Different international reports on the prevalence of physical activity vary greatly, depending on the definition of the term and type of questionnaire. Results of a shorter version of International Physical Activity Questionnaire within the scope of the World Health Survey, conducted in 51 countries during 2002-2003, report an $18 \%$ prevalence of physical activity ranging drastically between $2 \%$ and $52 \%$ in men and between $4 \%$ and $71 \%$ in women ${ }^{3}$, whereas a Greek study reports about $13 \%$ inactive men and $7 \%$ inactive women ${ }^{4}$.

According to 2003 and 2008 Croatian Adult Health Survey (CroHort Study), physical inactivity has become a significant public health issue in Croatia. Overall in $2003,30.5 \%$ of the Croatian population was considered physically inactive $(28.9 \%$ of men and $31.9 \%$ of women) $)^{5}$. The highest prevalence of physical inactivity in Croatia, for both genders in 2003, was recorded in the City of Zagreb (39.5\% men and $43.6 \%$ women). Regional distribution of physical inactivity in men was the lowest in Mountainous Croatia (14.1\%), and among women in the Eastern region $(24.7 \%)^{5}$. The negative trend was detected in 2008, where, according to the CroHort Study, as much as $60.7 \%$ of the subjects were physically less active than in 2003 , whilst at the same time only $4.5 \%$ became physically more active, by either walking or cycling to work ${ }^{6}$. The prevalence of physical inactivity in 2008 was $37.7 \%, 36.8 \%$ in men and $38.1 \%$ in women?

The Croatian Sport for All Federation estimates that the share of physically active population in Croatia oscillates between $7 \%$ and $10 \%$, as opposed to the Scandinavian and Central European countries boasting 50\% of physically active population. Unlike Croatia, the latter countries have recognized physical exercise as the key factor in health preservation, which essentially it is ${ }^{8}$. This recognition has also surfaced in a study by a German counselling company Brand:Trust. They discovered that Eastern Europeans and Asians lately find happiness in material things, whereas Westerners from developed countries rather crave non-materialistic luxuries, such as healthy, good psychophysical condition and education ${ }^{9}$. Research done in northwest Croatia on a sample of 81 participants shows that $41.9 \%$ of them spend their free time in some form of physical activity (walking, cycling, jogging, etc.). The dominant physical activity is walking, practiced by $30 \%$ of participants, while only $6 \%$ take up cycling ${ }^{10}$.

Previous studies have proved that self-perceived health correlates highly with an objective evaluation of the health status ${ }^{11}$. Physical activity status shows statistically significant correlation with health self-assessment in so far as the higher the intensity of physical activity, the better the self-perceived health ${ }^{12}$. Poorer physical activity positively correlates with lower self-perceived health in both healthy participants and participants with physical impairments or chronic diseases ${ }^{13}$. Lifestyle factors, including obesity, also affect self-perceived health ${ }^{14}$. Consequently, an elderly smoker would be less likely to assess his/her health as good ${ }^{12}$. It all points to the need of a subjective assessment of one's health and of the quality of information provided therein. Smoking and overweight today are priority public health issues throughout the world, partly due to a strong correlation with cardiovascular diseases ${ }^{15}$. Cardiovascular diseases are the leading cause of death in Croatia, taking nearly every other life ${ }^{16}$. The National Cardiovascular Disease Prevention Program has recognized the value of promoting cycling in the general population ${ }^{16}$. The prevalence of overweight in Croatia has been recorded at a rate of $37.7 \%$ and obesity at $18 \%^{17}$. If said alarming facts are complemented by the fact that $25 \%$ of the population are regular smokers $^{17}$, it becomes clear that rapid and resolute response via public health mechanisms is crucial.

Similar correlations between the lifestyle and selfperceived health came up solely in countries of similar socioeconomic conditions ${ }^{18}$. Studies conducted in Finland, as well as many other stable countries, have proven that self-perceived health is associated with health behaviour and may be used as a health indicator, while in the Baltic countries some other factors (like socio-psychological and socio-cultural) may take precedence ${ }^{19}$. The probability of a poor health status is significantly lower in persons who exercise sufficiently, when compared to inactive individuals ${ }^{20}$. 
Taking pleasure in physical activity drastically elevates the overall quality of life, improves psychological and physical condition, gives an opportunity to socialize and meet new people, increases intellectual capacities and spiritual fulfilment, as well as it helps run daily errands with more enthusiasm, while exercising in the nature builds a bond with the nature and raises awareness of the need to protect $\mathrm{it}^{21}$. Since cycling comprises all the above components and can be used as an inexpensive means of transportation, we can conclude that it is an ideal form of physical activity.

In Croatia, there are around 70 cycling clubs operating under the Croatian Cycling Federation, whose statutory tasks include development and promotion of cycling, support to competitive and recreational cycling, broadening of cycling activities, especially in children and youth, and popularization of cycling ${ }^{22}$. Thematic Guidelines from 2010, designed for the European Mobility Week, argue that cycling as a means of transport ensures regular activity, which can be easily, and with minimum expenses, integrated in the daily routine ${ }^{23}$, thus saving time - the modern man's asset - by exercising while travelling to work. Cycling is a good option for people of different ages and physical conditions, without a major risk of injury or health threats. Another well-known fact is that cycling is an aerobic activity serving to get the body as much oxygen as possible for optimum use. This is how our heart, lungs and blood vessels grow stronger, how we lose weight, and how we cope with psychological burdens and stress more easily.

Some previous researches show that cycling is associated with a lower risk of all-cause mortality ${ }^{24}$, with a better-perceived general health and quality of life $e^{25,26}$ and with lower levels of self-perceived stress ${ }^{27}$. Even after correcting risk factors, including physical activity during leisure time, participants who did not cycle to work had a $39 \%$ higher mortality than those who did $^{28}$. The authors find these data one of the strongest indicators of the benefits of cycling for overall human health. In a prospective study on Chinese women who cycled for transport, mortality dropped by $35 \%$, while walking was not as reliably correlated with risk reduction ${ }^{29}$. Several studies have shown that physical activity may play a vital role in primary prevention of cardiovascular diseases, while others report a negative impact of intense physical activity on this disease category, including myocardial infarction ${ }^{30}$. This, however, does not relate to cycling as Morris proved with his study; the incidence of myocardial infarction in cyclists being 50\% lower than in non-cyclists ${ }^{31}$. Despite this valuable piece of infor- mation, Morris still has raised concern with the finding that only $7 \%$ of the population regularly cycle. This calls for a more engaged promotion of cycling in the wider population. Croatian research of subjective well-being of cyclists, using the Personal Wellbeing Index, shows that the cyclists have higher quality of life than the inactive persons in the domain of health and in the overall index, which is an aggregate average score across the seven domains (standard of life, health, achievements in life, close relationships, personal safety, community connectedness and future security) ${ }^{32}$.

According to the European Health Interview Survey, which was conducted in Croatia in 2014 and 2015, $60.5 \%$ of the Croatian population uses the bicycle as a means of transport less than 30 minutes a day $(58.6 \%$ of men and $62.2 \%$ of women). As is expected, less people use bicycle as a means of transport more than $30 \mathrm{~min}$ utes per day, only $39.5 \%$ (62.2\% of men and $37.8 \%$ of women $)^{17}$.

Since Croatian researches have already shown that the cyclists have higher quality of life in the domain of health, the aim of this paper was to compare differences in all health dimensions between people who regularly (three or more times a week) use the bicycle as a means of transport with that of completely or mostly (less than three times a week) inactive people. This is a vehicle to point out the positive effect of cycling on self-perceived health and help spread awareness of the need and possibilities of using a bicycle for daily transport.

\section{Methods}

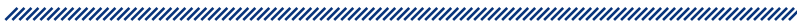

\section{Participants}

The study included 108 people using a bicycle three or more times a week for longer than half an hour, as a means of transport or recreation. The study excluded professional cyclists. The average participant age was 37 . Sixty-six participants were men $(61 \%)$ and 42 women (39\%). They were all recruited with the assistance of the Croatian cycling magazine "Baker" and a civil organisation that advocates the improvement of ecology ("Green Action"). The control group comprised 100 people who were physically active less than three times a week or took up no activity at all, with 
the average age of 39. Among control participants, 58 were men (58\%) and 42 women (42\%). Since there was much larger reservoir of potential control group participants (i.e. inactive people in the Croatian population) matched sampling was used in order to produce a control of comparable size that is similar to a treated group with respect to the distribution of observed covariates. The following criteria were applied in the selection of the control group: sex and age (+/- 5 years), residence and education. Inclusion criteria were the absence of any chronic physical illness that could disable the implementation of moderate physical activity. The control group was recruited with the assistance of cycling clubs and general practitioners in the municipalities of residence of the cyclists included in the study. Most participants in both groups had higher education (62\%), while $37 \%$ had a high school diploma. Only two subjects (1\%) had completed primary school only. Considering the selective pattern of the control group, no significant differences were observed among groups in terms of age or level of education.

Limitation of this study is that the convenience sample of participants was used and that data regarding other forms of physical activity in which participants participated as well as data about participants' history of cycling were not collected.

\section{Methods}

Health status was self-assessed using a health status questionnaire - the Croatian version of SF-36 33,34 . SF-36 is a short multifunctional health questionnaire comprising 36 questions ${ }^{34}$ divided into eight domains. SF-36 represents a theoretically based and empirically authenticated operationalisation of two general health concepts - physical and psychological health - and their two general manifestations, functioning and wellbeing. The eight domains that SF-36 measures are as follows:

\section{Physical functioning (PF)}

It assesses the extent to which the participants' perceptions of their quality of life are influenced by their physical condition. It refers to the extent to which the participants can perform vigorous activities (running, lifting heavy objects, participating in strenuous sports, climbing several flights of stairs and walking more than a kilometre) but also entails the performance of moderate activities (bending, kneeling or stooping, bathing and dressing themselves). This domain has 10 questions.

\section{Role limitations due to physical problems (RP)}

It refers to the extent to which participants' performance of their daily activities interfere with their physical state of health (their ability to perform vigorous activities such as lifting heavy objects or to perform moderate activities such as pushing a vacuum cleaner). This domain has four questions.

\section{Bodily pain (BP)}

It assesses the extent to which the participants' experience of bodily pain interfere with their performance of daily activities (work-related duties in the public domain and tasks within the home environment). This domain has two questions.

\section{Perception of general health $(\mathrm{GH})$}

It evaluates personal health in general (excellent, very good, good, fair or poor, getting ill easier than other people do, and just as healthy as anyone he/ she knows) and is made of five questions.

\section{Vitality and energy (VE)}

It relates to the participants' experience of feeling energetic and full of pep, or worn out and tired, and it measures energy and vitality. This domain has four questions.

\section{Social functioning (SF)}

It refers to social activities and interaction with significant people (family members, friends). This domain has two questions.

\section{Role limitations due to emotional problems (RE)}

It assesses the extent to which the emotional condition of the participants interferes with their daily functioning and ability to perform roles. This domain has three questions.

\section{Mental health (MH)}

It assesses psychological distress and well-being measuring happiness, nervousness and depression. This domain has five questions ${ }^{35}$.

A single question that identifies self-perceived change in health in the last year is also included, making SF-36 a useful indicator for change in quality of life over time and treatment ${ }^{33,35}$.

For the summary measures, scales PF, RP and BP refer to the general measure of physical health; scales SF, RE and $\mathrm{MH}$ measure psychological health and scales VE and $\mathrm{GH}$ represent global measures of health in general. Total score is expressed as a profile defined by eight points that are represented by measurements of individual health aspects transposed into a standardized 
scale of zero (minimum) to 100 (maximum). The higher the result in each scale, the better the subjective health. Psychometric evaluation showed good psychometric qualities of the Croatian version of SF- $36^{34}$. The demographic part of the questionnaire contained data on sex, age, residence, and education ${ }^{8}$.

Differences between the groups were analysed by ttest, while category data distributions were tested by $\chi 2$ test. STATISTICA, ver. $7.1^{36}$ program support was used for the analysis.

\section{Results}

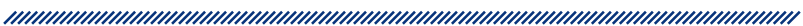

A statistically significant difference was observed in all health dimensions between cyclists and inactive persons (Table 1). Cyclists perceived their health drastically better than the physically inactive participants. The poorest health dimensions in physically inactive individuals were vitality and energy, psychological health, and role limitation due to emotional problems.

Another statistically important difference was observed between the groups in changes in health, where $16.7 \%$ of cyclists claimed to be of much better health than a year ago, as did only $2 \%$ of inactive participants. A difference was also observed in the segment of health deterioration relative to a year ago - $30 \%$ of inactive participants stated their health worsened as compared to a year ago, as did $8 \%$ of cyclists. While $4 \%$ of inactive participants felt their health deteriorated drastically, no cyclists thought likewise (Table 2).

\section{Discussion and Conclusion}

According to the definition of the World Health Organization, "health is a state of complete physical, mental and social well-being and not merely the absence of

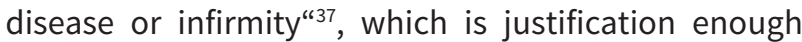
for a study on self-perceived health status. Health selfassessment reflects a comprehensive perception of health, including one's biological, psychological and social dimensions, otherwise hidden to an outside observer. Health self-assessment is affected by numerous factors difficult to objectify, which in no way implies that this method should be avoided.

\begin{tabular}{|c|c|c|c|c|c|c|}
\hline Health dimension & Activity & $\mathrm{N}$ & $\mathrm{M}$ & $\mathrm{SD}$ & $\mathrm{t}$ & $\bar{p}$ \\
\hline \multirow{2}{*}{ Physical functioning } & cyclists & 108 & 87.31 & 20.34 & & \\
\hline & inactive & 100 & 76.15 & 25.32 & 3.48 & .001 \\
\hline \multirow{2}{*}{$\begin{array}{l}\text { Role limitation due to physical } \\
\text { problems }\end{array}$} & cyclists & 108 & 87.96 & 24.76 & & \\
\hline & inactive & 100 & 73.50 & 38.41 & 3.20 & .002 \\
\hline \multirow{2}{*}{$\begin{array}{l}\text { Role limitation due to } \\
\text { emotional problems }\end{array}$} & cyclists & 107 & 80.99 & 32.41 & & \\
\hline & inactive & 99 & 64.31 & 39.05 & 3.32 & .001 \\
\hline \multirow{2}{*}{ Social functioning } & cyclists & 106 & 86.44 & 16.29 & & \\
\hline & inactive & 99 & 74.49 & 21.72 & 4.47 & $<.001$ \\
\hline \multirow{2}{*}{ Mental health } & cyclists & 99 & 73.49 & 13.52 & & \\
\hline & inactive & 100 & 64.28 & 17.85 & 4.10 & $<.001$ \\
\hline \multirow{2}{*}{ Energy and vitality } & cyclists & 101 & 66.68 & 14.99 & & \\
\hline & inactive & 100 & 52.00 & 20.29 & 5.84 & $<.001$ \\
\hline \multirow{2}{*}{ General health perception } & cyclists & 103 & 77.32 & 13.41 & & \\
\hline & inactive & 100 & 63,21 & 21.09 & 5.67 & $<.001$ \\
\hline
\end{tabular}




\begin{tabular}{|c|c|c|c|c|}
\hline \multirow{2}{*}{\multicolumn{2}{|c|}{ Health relative to one year ago }} & \multicolumn{2}{|c|}{ Activity } & \multirow[b]{2}{*}{ total } \\
\hline & & \multirow{2}{*}{$\begin{array}{c}\text { cyclists } \\
18\end{array}$} & \multirow{2}{*}{$\begin{array}{c}\text { inactive } \\
2\end{array}$} & \\
\hline \multirow{2}{*}{ much better } & Count & & & 20 \\
\hline & $\%$ & $16.7 \%$ & $2.0 \%$ & $9.6 \%$ \\
\hline \multirow{2}{*}{ somewhat better } & Count & 28 & 15 & 43 \\
\hline & $\%$ & $25.9 \%$ & $15.0 \%$ & $20.7 \%$ \\
\hline \multirow{2}{*}{ about the same } & Count & 54 & 53 & 107 \\
\hline & $\%$ & $50.0 \%$ & $53.0 \%$ & $51.4 \%$ \\
\hline \multirow{2}{*}{ somewhat worse } & Count & 8 & 26 & 34 \\
\hline & $\%$ & $7.4 \%$ & $26.0 \%$ & $16.3 \%$ \\
\hline \multirow{2}{*}{ much worse } & Count & 0 & 4 & 4 \\
\hline & $\%$ & $.0 \%$ & $4.0 \%$ & $1.9 \%$ \\
\hline \multirow[t]{2}{*}{ Total } & Count & 108 & 100 & 208 \\
\hline & $\%$ & $100.0 \%$ & $100.0 \%$ & $100.0 \%$ \\
\hline
\end{tabular}

For the present study, SF-36 questionnaire was used as a theoretically founded and empirically verified operationalisation of two main health aspects, physical and psychological. The questionnaire has been proven a valuable and reliable instrument in an analysis of a subjective evaluation of the health of the Croatian population ${ }^{34}$. The result is, standardly, broken down to eight dimensions, which make up a health status profile. The results show that cyclists in all dimensions of self-assessment had statistically significantly better health, which is in correlation with previous researches. Differences are particularly prominent in the domains of role limitations due to physical and emotional problems, also keeping in line with the previous studies which showed that physical activity is effective in promoting psychological well-being mostly by improving the mood and self-confidence ${ }^{38}$, the effects of which are noticeable in all age groups independently of the socioeconomic or health status ${ }^{39}$. Physical condition is often perceived as the amount of effort needed to run daily errands ${ }^{11}$. This research confirmed that cyclists have considerably fewer physical limitations in running daily errands, which is consistent with research that says that those who maintained cycle commuting report lower sickness absence than those who don 't cycle to work ${ }^{40}$. However, it is possible that people with fewer physical limitations in running daily errands are more likely to cycle. For people who estimate their health as poor, fa- tigue usually is a reliable indicator of health, while in people who describe their health as excellent, fatigue rarely has any bearing on the way they perceive their health, similarly as with the domain of pain ${ }^{41}$.

The same surfaced in this study - the group of cyclists had significantly better results in the domains of vitality and pain, as they did in social functioning, but interpretation of this is also limited. The reason could be that socializing among cyclists contributed to a better status. It is a well-known fact that man is a social being and that socializing has a positive effect on him. On the other hand, people who suffer pain are less likely to cycle in the first place.

In the domain of change in health over the last year, a surprising $16.7 \%$ of cyclists reported a radical health improvement in comparison with a year ago, as did only $2 \%$ of inactive participants. More or less the same health condition was reported by $50 \%$ of cyclists and by $53 \%$ of inactive population. A total of $42.6 \%$ cyclists and no more than $17 \%$ of their inactive counterparts declared having better health than last year. In a study by Miilunpao et al., on a general population sample, $60 \%$ of participants assessed their health the same as a year ago, with a very low percentage of significant change in the health status ${ }^{11}$. Said data speak in favour of the reliability of self-perceived health, as does the present study, where $4 \%$ of inactive participants 
claimed to have worse health than last year, as did none of the interviewed cyclists. However, a staggering $26 \%$ of inactive people estimated their health to be somewhat poorer than last year, as did $7.4 \%$ cyclists. There is no doubt that cycling has a positive effect on selfperceived health, which not only significantly improves, but also shows a tendency to linger over the years.

Since researches have shown that Croatian citizens spend the least energy on transport, followed by leisure activities $^{42}$, echoing other countries, it implicates there is a vast area of correlation between physical activity and transport. Cycling to work would not take up too much time in one's busy schedule, while positively affecting one's physical, psychological and social functioning in a far-reaching way.

Social and lifestyle factors today are priority public health issues throughout the world and they are closely linked to self-perceived health. Since this research shows that cyclists perceive their health drastically better than the physically inactive participants do, it is necessary to further investigate the relationship between lifestyle factors and cycling and then implement cycling into the public health campaigns aiming at not just an ordinary promotion of physical activity, but rather at raising public awareness about the negative effects of inactivity. Today, this is considered a necessity as less than $40 \%$ adults in the western countries regularly take up any kind of physical activity, which calls for urgent intervention and promotion of physical activity in the general population ${ }^{43}$.

A resulting conclusion is that cyclists perceive their health drastically better than the physically inactive participants do, but this research, unfortunately, does not point to the causal link between mentioned health domains and cycling. Thus, a new research, which would see into the causal link between health domains and cycling, is necessary. Also, there are other factors that influence self-assessment of health, such as lifestyle, psychosocial and material conditions and they also need to be incorporated in the next researches, as well as the link between intensity of cycling and the benefit on self-perceived health.

\section{References}

1. World Health Organization. 1984. Accessible at the address: http://www.who.int/topics/physical_activity/en/ Information access date February 23, 2011.

2. World Health Organization. 2011. Accessible at the address: http://www.who.int/mediacentre/news/notes/2011/ world_cancer_day_20110204/en/Information access date February 23, 2011.

3. Guthold R, Ono T, Strong KL, Chatterji S, Morabia A. Worldwide Variability in Physical Inactivity: A 51-Country Survey. Am J Prev Med. 2008;34(6):486-94.

4. Varo JJ, Martínez-González MA, de Irala-Estévez J, Kearney J, Gibney M, Martínez JA. Distribution and determinants of sedentary lifestyles in the European Union. International Journal of Epidemiology. 2003;32:138-46.

5. Milošević M, Golubić R, Mustajbegović J, Doko Jelinić J, Janev Holcer N, Kern J: Regional Pattern of Physical Inactivity in Croatia. Collegium Antroplologicum. 2009;33(1):35-38.

6. Missoni E, Kern J, Missoni I: Physical Inactivity Changes in Croatia: The CroHort Study. Collegium Antropologicum. 2012;36(1):257-259.

7. Marić Bajs M, Andrić A, Benjak T, Vuletić G: Five Year Cumulative Incidence of Physical Inactivity in Adult Croatian Population: The CroHort Study. Collegium Antropologicum. 2012;36(1):89-93.

8. Kinkela D, Đonlić $V$, Moretti V. Lifelong physical training for sustainable development. In: Uzelac V, Vujičić L, editors. Lifelong Learning Sustainable Development. University of Rijeka: Faculty of Teacher Education, Rijeka, 2008:281.

9. Odisej. Biz Portal. 2007. Accessible at the address: http:// www.odisej.biz/revija/clanak.asp?id=4431 Information access date February 25, 2011.

10. Jertec Nenad. Analysis of perception and preferences in physical activity and kinesiology in residents of Northwestern Croatia, Croatian Kinesiology Association, 19. 2010. Summer school of kinesiology, Croatia. Accessible at the address: http://www.hrks.hr/skole/19_ljetna_ skola/35-Jertec.pdf. Information access date February 25, 2011.

11. Miilunpalo S, Vuori I, Oja P, Pasanen M, Urponen H. SelfRated Health Status as a Health Measure: The Predictive Value of Self-Reported Health Status on the Use of Physician Services and on Mortality in the Working-Age Population. J Clin Epidemiol. 1997;50(5):517-528.

12. Abu-Omar K, Rutten A, Robine JM. Self-rated health and physical activity in the European Union. Soz Praventivmed. 2004;49(4):235-242.

13. Han M.A, Kim K.S, Park J, Kang M.G, Ryu S.Y. Association between levels of physical activity and poor self-rated health in Korean adults: The Third Korea National Health and Nutrition Examination Survey (KNHANES), 2005. Public Health. 2009;123:665-669. 
14. Molarius A, Berglund K, Eriksson C, Lambe M, Nordstrom E, Eriksson HG, Feldman I. Socioeconomic conditions, lifestyle factors, and self-rated health among men and women in Sweden. Eur J Public Health. 2007;17(2):125-133.

15. WHO. Guidelines for Controlling and Monitoring the Tobacco Epidemic. WHO, Geneva 1998.

16. Institute of Public Health, District: Primorsko - goranski, Croatia. National Cardiovascular Disease Prevention Program. Accessible at the address: http://www.zzjzpgz.hr/ nzl/12/program.htm Information access date March 28, 2011.

17. Croatian Institute of Public Health. European Health Interview Survey (EHIS) in Croatia 2014-2015. Basic Indicators. Zagreb. 2016.

18. Södergren M, Sundquist J, Johansson S, Sundquist K. Physical activity, exercise and self-rated health: a population-based study from Sweden. BMC Public Health. 2008;8:352.

19. Kasmel A, Helasoja V, Lipand A, Prattala R, Klumbiene J, Pudule I. Association between health behaviour and seIf-reported health in Estonia, Finland, Latvia and Lithuania. Eur J Public Health. 2004;14(1):32-36.

20. Brown DW, Balluz LS, Heath GW, Moriarty DG, Ford ES, Giles $\mathrm{WH}$, et al. Association between recommended levels of physical activity and health-related quality of life. Findings from the 2001 Behavioral Risk Factor Surveillance System (BRFSS) survey. Prev Med. 2003;37:520-8.

21. Janković S. Fifty Tips for Health. Zagreb: Croatian National Institute of Public Health, 2003.

22. Croatian Cycling Federation. 2007. Accessible at the address: http://www.hbs.hr/pdf/statut.pdf Information access date February 25, 2011.

23. Ministry of Environmental Protection, Physical Planning and Construction, Croatia (2010). Accessible at the address: http://www.mzopu.hr/doc/Tematske_smjernice_2010.pdf Information access date February 25, 2011.

24. Kelly P, Kahlmeier S, Götschi T, et al. Systematic review and meta-analysis of reduction in all-cause mortality from walking and cycling and shape of dose response relationship. The International Journal of Behavioral Nutrition and Physical Activity. 2014;11:132. doi:10.1186/ s12966-014-0132-x. Accessible at the address: https:// www.ncbi.nlm.nih.gov/pmc/articles/PMC4262114/. Information access date August 18, 2107.

25. Bopp M, Kaczynski AT, Campbell ME. Health-Related Factors Associated with Mode of Travel to Work. Journal of Environmental and Public Health. Vol. 2013, Article ID 242383, 9 pages, 2013. doi:10.1155/2013/242383. Accessible at the address: file:///C:/Users/zdrausnik/Downloads/242383. pdf. Information access date August 18, 2107.

26. Scheepers CE, Wendel-Vos GCW, van Wesemael PJV, et al. Perceived health status associated with transport choice for short distance trips. Preventive Medicine Reports. 2015;2:839-844. doi:10.1016/j.pmedr.2015.09.013. Accessible at the address: https://www.ncbi.nlm.nih.gov/pmc/articles/ PMC4721281/. Information access date August 18, 2107.

27. Avila-Palencia I, Cole-Hunter T, de Nazelle A, Donaire D,
Jerrett M, Nieuwenhuijsen M. The relationship between bicycle commuting and levels of self-perceived stress. Journal of Transport \& Health. Volume 2, Issue 2, Supplement, June 2015, Page S27. Accessible at the address: http://www. sciencedirect.com/science/article/pii/S2214140515005848. Information access date August 18, 2107.

28. Andersen L, Schnohr P, Schroll M, Hein H. All-cause mortality associated with physical activity during leisure time, work, sports, and cycling to work. Archives of Internal Medicine. 2000;160:1621-1628.

29. Matthews C, Jurj AL, Shu X, Li H, Yang G, Li Q et al. Influence of Exercise, Walking, Cycling, and Overall Nonexercise Physical Activity on Mortality in Chinese Women. American Journal of Epidemiology. 2007;165(12):1343-1350.

30. Gyntelberg F, Lauridsen L, Schubell K. Physical fitness and risk of myocardial infarction in Copenhagen males aged 40-59: a five- and seven-year follow-up study. Scand J Work Environ Health. 1980;6(3):170-8.

31. Morris JN. Cycling and health. In: Proceedings From Friends of the Earth Conference, London. London, England: Hammerschmidt \& Fulham. 1990; pp. 14-19.

32. Lovretić V, Benjak T, Vuletić, G. Subjective Wellbeing of Cyclists and Physically Inactive Subjects. Kinesiology 45(2013) 1:101-106.

33. Ware JE, Kosinski M, Gandek B. SF-36 Health Survey. Manual and interpretation guide. Lincoln (RI): Quality Metric Inc; 1993.

34. Maslić Seršić D, Vuletić G. Psychometric Evaluation and Establishing Norms of Croatian SF-36 Health Survey: Framework for Subjective Health Research. Croat Med J. 2006;47:95-102.

35. Vuletić Mavrinac G, Maslić Seršić D, Mujkić A. Cardiovascular and Behavioral Risk Factors in Relation to Self-Assessed Health Status. Coll. Antropol. 33 (2009) Suppl. 1. 99-106.

36. STATISTICA, wer.7,1; StatSoft, Inc., 2005.

37. Constitution of the WHO. In: Handbook of basic documents. 5th edition. Geneva: World Health Organization, Palais des Nations; 1952:3.

38. Fox K. The influence of physical activity on mental wellbeing. Public Health Nutrition. 1999;2(3a):411-418.

39. Biddle, S. J. H. Emotion, mood and physical activity. In: S. J. H. Biddle, K. R. Fox \& S. H. Boutcher.Physical activity and psychological well-being. London, Routledge, 2000; pp. 63-87.

40. Mytton OT, Panter J, Ogilvie D. Longitudinal associations of active commuting with wellbeing and sickness absence. Preventive Medicine. 2016;84:19-26. doi:10.1016/j. ypmed.2015.12.010. Accessible at the address: https:// www.ncbi.nlm.nih.gov/pmc/articles/PMC4766368/. Information access date August 18, 2107.

41. Kaplan G, Baron-Epel O. What lies behind the subjective evaluation of health status? Social Science \& Medicine. 2003;56:1669-1676.

42. Jurakić $D$, Pedišić Ž, Andrijašević M. Physical Activity of Croatian Population: Cross-sectional Study Using International Physical Activity Questionnaire. Croat Med J. 2009;50:165-173.

43. Seefeldt V, Malina RM, Clark MA. Factors affecting levels of physical activity in adults. Sports Med. 2002; 32:143- 168. 


\section{KOMPARATIVNA STUDIJA SAMOPROCJENE ZDRAVLJA BICIKLISTA I NEAKTIVNIH OSOBA U HRVATSKOJ}

\section{Sažetak}

Cilj: Cilj ove studije bio je usporediti samoprocjenu zdravlja osoba koje redovito (tri ili više puta tjedno) voze bicikl u svrhu transporta i onih koje su većinom ili u potpunosti neaktivne (manje od tri puta tjedno).

Metode: Istraživanje uključuje 108 osoba koje tri i više puta tjedno voze bicikl duže od pola sata. Prosječna dob ispitanika bila je 37 godina. Šezdeset i šest ispitanika bili su muškarci (61 \%) i četrdeset i dvije žene (39\%). Kontrolna skupina sadržava 100 osoba prosječne dobi 39 godina. Među kontrolnim ispitanicima 58 su bili muškarci (58 \%), a 42 žene (42\%). Samoprocjena zdravlja vršila se s pomoću hrvatske verzije upitnika zdravstvenog stanja SF-36.

Rezultati: Uočena je statistički značajna razlika u svim domenama zdravlja između biciklista i neaktivnih osoba. Najniže zdravstvene dimenzije u neaktivnih pojedinaca bile su vitalnost i energija, psihičko zdravlje i ograničenja zbog emocionalnih problema. Ukupno 42,6 \% biciklista i ne više od $17 \%$ neaktivnih osoba izjavilo je da im je zdravlje bolje nego prošle godine. Razlika je također uočena i u segmentu pogoršanja zdravlja u odnosu na prošlu godinu - $30 \%$ neaktivnih ispitanika izjavilo je da im se zdravlje pogoršalo u odnosu na prošlu godinu, a isto je izjavilo samo $8 \%$ biciklista. Dok $4 \%$ neaktivnih ispitanika smatra da im se zdravlje drastično pogoršalo, nitko iz skupine biciklista ne misli tako.

Zaključak: Biciklisti doživljavaju svoje zdravlje mnogo boljim nego neaktivne osobe. Faktori stila života koji utječu na samoprocjenu zdravlja mogli bi biti važno objašnjenje.
Ključne riječi: biciklisti, samoprocjena zdravlja, tjelesna aktivnost, tjelesna neaktivnost, Hrvatska 